\title{
The consequences of delegation to independent agencies: Separation of powers, discursive governance and the regulation of telecommunications in Germany
}

\author{
THOMAS GEHRING \\ Faculty of Social and Economic Sciences, University of Bamberg, Germany
}

\begin{abstract}
Whereas the delegation of regulatory powers is usually examined from the principal's perspective, this article explores the consequences of delegation for the regulatory output. Empirically, it finds that the dissolution of the original German postal authority led to the establishment of a system of divided labour in which different actors, including an (almost) independent regulatory agency, depend on each other's performance of specialized functions. Theoretically, it contributes to the ongoing debate over the role and operation of independent agencies in two main respects. First, based on the modern theory of social systems, it draws attention to the fact that the reform process was characterized by an increased functional differentiation of institutionalized decision-making. Second, drawing on the Habermasian theory of communicative action, it is argued that functional differentiation supports the transformation of interaction from interest-based bargaining to deliberative arguing both in the legislative and the administrative arenas. As political actors are made unable to resort to their power resources, reasons become a key source of influence.
\end{abstract}

Independent regulatory agencies are a modern form of market regulation. While they were invented in the United States in the nineteenth century to protect administrative decision-making from partisan politics (Shapiro 1988), they have now spread all over the Western world with the task of regulating the public utilities (Majone 1996; Thatcher \& Stone Sweet 2002). They also appear in the form of independent central banks or cartel offices. Even new political systems such as the European Union (Egan 1998) and polities with little experience in delegating functions to 'arm's length' institutions like Germany are increasingly coming to establish largely independent regulatory agencies (Döhler 2002).

For a traditional 'Principal-Agent' approach, it is difficult to explain why legislatures establish regulatory agencies and central banks that are more or less independent from their principals because the approach focuses primarily on oversight. Delegation always establishes new actors that may develop and pursue their own interests, rather than those of their principals (Moe 1990: 121). Inevitably, it generates 'agency losses' and requires that efforts be made to ensure that an entrusted agent does that for which it was established.

E European Consortium for Political Research $2(0) 4$

Published by Blackwell Publishing L.td., 960) Garsington Road, Oxford, OX4 2DQ. UK and 350 Main Strett. Malden. MA 02148. USA 
Whereas earlier theories of bureaucracy claimed that administrations were hard to control (Niskanen 1971), studies using the Principal-Agent framework attempted to assess the actual margin of discrete choice enjoyed by an agency. Inspection of the political system in the United States revealed that Congress may, for example, closely supervise the activities of its agents (McCubbins \& Schwartz 1987; Hopenhayn \& Lohmann 1996), prescribe administrative procedures (McCubbins et al. 1987; Epstein \& O'Halloran 1994), control an agency's budget and appoint its executives (Huber 2000), or adopt detailed legislation to limit discretion (Huber et al. 2001). Successful oversight does not necessarily require explicit action because an agent may anticipate sanctions and adapt to the principal's expectations (Pollack 2002: 202).

If relative independence is granted to a public body in order to keep regulatory decision-making at arms' length from the grip of the legislator, an agency can no longer be an agent in the understanding of Principal-Agent theory. Rather, it becomes a fiduciary entrusted with discretion to pursue a principal's interest without immediate oversight by the latter (Majone 2001; Stone Sweet 2002). To be sure, a principal will generally expect to benefit from division of labour and specialization (Coleman 1990: 146; Kiewiet \& McCubbins 1991: 22-24). A legislative majority may want to tie subsequent governments to their regulatory decisions (see Shepsle 1992 on coalitional drift). Likewise, a legislator may assume that private investors do not become active in a sector of the public utilities unless they expect long-term stability of regulation (Majone 1996:5-6). In all these cases, oversight by the principal is no longer the predominant issue.

The consequences of assigning competencies to an independent regulatory agency remain to be examined. Once the agency has been established, it begins to bind, and thus 'control', the original principal. However, the diminishing relevance of immediate oversight by the principal must not be interpreted as absence of the problem of agency shirking (Shepsle 1992) or as unlimited freedom to act arbitrarily. More sophisticated oversight arrangements are required to make the agency accountable for its decisions without undermining its independent decision-making function (Majone 1999; Thatcher \& Stone Sweet 2002). The principal will not only delegate decision-making power, but also establish a more comprehensive oversight system. Therefore, authority relations of independent agencies are difficult to locate on the traditional continuum between tight oversight/less discretion and little oversight/more discretion that underlies traditional Principal-Agent analyses (Epstein \& O'Halloran 1999).

This article examines the consequences of the re-organization of telecommunications in Germany during the 1990s, accompanied by the establishment of an (almost) independent regulatory agency within an administrative setting 
with little experience of independent administrations (Döhler 2002; Müller 2001). Following the modern theory of social systems (Luhmann 1984, 2000), it draws attention to the fact that the reform process was characterized by increased functional differentiation of institutionalized decision-making. Drawing on the Habermasian theory of communicative action (Habermas 1992), the article argues that functional differentiation supports the transformation of interaction from interest-based bargaining to deliberative arguing both in the legislative and the administrative arenas.

Two theoretical innovations are put forward, which are relevant for the analysis of independent agencies and their consequences beyond the German case. First, a regulatory system that includes an independent agency is conceptualized as a non-hierarchical system of divided labor; thereby avoiding the narrow focus on the activities, or degree of independence, of the agency and taking seriously the fact that the reform process was characterized by an increased functional differentiation of institutionalized decision-making. These regulatory systems consist of different sub-systems, each of which is specialized on particular functions that complement each other. Regulation emerges from this system as a joint product that is beyond the grip of any single actor involved, including the legislator and the agency. In this perspective, the research focus shifts from discretion and oversight to the distribution of functions between the sub-systems involved, their specific rationales of decision-making as well as the effects of this division of labour, including the modes of integration of partial decisions into a reasonable regulatory output (Hancher \& Moran 1989).

Second, attention is drawn to the fact that establishing a system of divided labour has repercussions on the interaction within the various sub-systems. Effects will depend on the functions allocated to a particular sub-system. The most important division in the German regulatory system of the telecommunication sector - and indeed in many other cases - is the separation of two core functions: rule-making is assigned to parliament and a closely related ministry, while the application of these rules is assigned to the regulatory agency. It is argued here that this particular institutional arrangement supports the transformation of interaction in both functional areas from interest-based bargaining to deliberative arguing (Elster 1998) because it makes it difficult for political actors to rely on their power resources, and forces them to reason and convince their counterparts (Thatcher \& Stone Sweet 2002: 19).

The article is organized as follows. First, I trace the process of regulatory change in Germany with emphasis on the organization of the German state supervisory system, rather than market liberalization. Subsequently, I relate this process to the sociological theory of social systems and argue that the established sub-systems follow distinct decision-making rationales. In the next 
section, I look more closely at the tasks assigned to the different state actors responsible for regulation within the current (new) system and explain the separation of legislative/executive and agency functions by the difference between short-term and long-term interests. In the following section, I examine the effects of functional differentiation on decision-making by both legislator/executive and agency. I argue that functional differentiation facilitates discursive (deliberative) interaction at both levels. The article concludes that a particular form of the division of regulatory functions may constitute a source for deliberative decision-making that side-steps parochial interests and allows for outcomes that are reasonable in a Habermasian sense.

\section{Regulatory change and functional differentiation in German telecommunications}

\section{The targets of postal reform: Market liberalization and organizational change}

Until 1989, the German telecommunications market was dominated by an encompassing state authority that included the Post Office and the Ministry of Post and Telecommunication. The authority supplied telecommunication and postal services and simultaneously supervised its own activities. While the Post Office (Deutsche Bundespost), as the actual provider of services, had in German law the status of an actor able to act in its own name and enjoying legal standing vis-à-vis its customers, suppliers and employees, it did not act independently from the supervising Ministry. The Minister of Post and Telecommunication acted as ministerial supervisor both of the Post Office and its chief executive. Based on direct chain of command from the Minister to every postal worker, all economic decisions were subject to oversight by the federal government (Steinmetz 1956: 33-34). The Post Office also had little financial autonomy - while it had its own budget, prices for its services were fixed by inter-ministerial coordination (Werle 1990: 83). Moreover, the Ministry was almost entirely financed by the Post Office rather than by the general government budget like other federal ministries.

By the end of the 1980s, this longstanding structure was undermined by a number of important developments. Technological progress fostered supplier interest in the liberalization of some parts of the market (Werle 1990: 226-243). The European Community developed a strategy of step-by-step liberalization of telecommunication markets (Schmidt 1998). There was also widespread doubt that a state-organized authority would be able successfully to participate in a rapidly growing market (Benz 1997: 286-288) because it was prevented from entering foreign markets. Finally, the Post Office could not 
mobilize the necessary capital to finance the modernization, or rather complete reconstruction, of the East German network without access to capital markets or financial support from the federal budget (Schmidt 1996: 52-53). Both market liberalization and a re-organization of the postal authority were needed.

In the first stage (Postreform I, after 1989), the Post Office was organizationally separated from the Ministry. Henceforth, it was led by the executives of the three economic branches (Deutsche Telekom, henceforth Telekom, as well as postal and banking services). It gained some financial autonomy and the Ministry came to be financed by the general state budget. Yet the enterprise remained integrated in the administrative system of the Ministry because a constitutional provision (Grundgesetz, former Article 87.1) required organization of postal and telecommunication services in the form of a federal administration (Schmidt 1996: 46-47).

This incomplete separation of functions was unfortunate in several ways, especially in light of the limited market liberalization of some customer and value-added services brought in at the same time (Humphreys 1992). The predominantly small suppliers entering the newly liberalized sectors of the market faced a regulatory agency that was closely related to their main competitor and might have been expected not to favour them (Riehmer 1995: 383). Conversely, the Post Office, as a part of the ministerial administrative structure, was, in spite of its new autonomy, not allowed formally to challenge directives of the Ministry (see parliamentary papers BT-Drs. 11/2854: 39), even though conflicts of interest might occur in the partially liberalized market. Accordingly, the Ministry was still able to exert considerable influence on economic decisions (Gramlich 1997:615). Finally, the Post Office remained a state administration that was not able to tap the capital markets and still suffered from a comparative disadvantage $v i s-\grave{a}$-vis its international competitors (Berger 1993: 91-92).

In the second stage (Postreform II, after 1995), organizational devolution proceeded in two areas. Based on a constitutional amendment that required two-thirds majorities in both chambers of parliament, economic activities were completely separated from the administrative structure of the Ministry and assigned to three independent, although still state-owned, stock corporations (Schmidt 1996: 55-58). Consequently, the companies gained legal standing $v i s-\grave{a}-v i s$ the supervising Ministry. The functions of the Ministry were, in turn, reduced to those of regulating private companies under administrative law. Oversight was no longer based on internal organizational hierarchy. Within the administrative structure of the Ministry, an area of semi-autonomous decision-making emerged. Separate chambers were established to decide conflicts between competing companies, including the former monopoly supplier. The 
Ministry was not only empowered to issue mandatory directives, it was also able to revise decisions adopted by the chambers in their quasi-judicial function. The limited autonomy of the chambers was justified by the general responsibility of the federal administration towards parliament (BT-Drs. 12/8108: 110). Hence, political intervention became more difficult than before, but it was by no means impossible.

In the third stage (Postreform III, after 1998), the telecommunications market was entirely liberalized and the organization of the regulatory function changed once again. The decision chambers originally embedded within the administrative structure of the Ministry became the core of the newly founded regulatory agency, Regulierungsbehörde für Telekommunikation und Post (Geppert et al. 1998: 529-545). The original Ministry of Post and Telecommunication was abolished. Its remaining ministerial functions - for example, preparation of new legislation and representation of Germany in international organizations as well as in the European Union - were assigned to a new department in the Ministry of Economic Affairs. According to the new system, decisions of the regulatory agency are still subject to general directives issued by the relevant Ministry, but such orders are no longer based on ministerial hierarchy, but rather are instruments for conducting relations between independent federal administrations and have to be published in the official Federal Gazette, the Bundesanzeiger. Moreover, the Ministry is now prevented from making or modifying Regulatory Agency decisions. Hence, while the agency is not fully independent from the supervising ministry (Gramlich 1998), it enjoys at least as much freedom as the Federal Cartel Office (Baake \& Perschau 1996).

To conclude, the three-step reform process led not only to an almost complete liberalization of the market for telecommunication services in Germany, but also to a profound reorganization of the state activities in the sector. The companies of the former Post Office were transformed into privately operating entities, while state activities were reduced to the regulation of suppliers in the market. In this context, a largely independent regulatory agency emerged as a new player on the scene. Hence, the reform constituted a process of gradual differentiation of functions that was not only limited to the established agents but involved the principal as well.

\section{Theoretical implications of functional differentiation}

In order to grasp the implications of functional differentiation, I will draw on the sociological theory of social systems (Luhmann 1984; Münch 1994: 271-305). In contrast to the usual Principal-Agent perspective on regulation 
and agencies, this theory is not preoccupied with hierarchy and the ability or inability to control, but sheds light on the operation of a functionally differentiated system. In a nutshell, a social system emerges as a new entity from communication between actors. It is separated from its environment by its own boundaries. Across these boundaries, it extracts bits of information from its environment and processes them according to its own internal programme. Hence, a social system operates as a selector that reduces complexity by 'observing' its environment according to its own selection criteria. Organizations that produce decisions constitute a particularly identifiable type of social system (Luhmann 2000).

As any social system, an organization may increase its selectivity and attention for the range of relevant information by the formation of sub-systems that specialize in the performance of certain tasks (Luhmann 1984: 259-260). A sub-system can afford to specialize in some functions relevant for the larger social system because other functions are performed by other sub-systems focusing on different tasks. Sub-systems operate, so to speak, in a context of divided labour. From a functional point of view, no stage of a differentiated decision process is per se more important than any other. Functional differentiation of a decision process promises to enhance the performance of the larger system (Mayntz 1988) - much as division of labour may increase the productivity of a production process.

An analytical perspective informed by systems theory draws attention to three aspects of the process of postal reforms.

1. Functional differentiation has to do with boundaries between subsystems. During the process of postal reform, existing internal boundaries between the sub-units of the postal authority as a whole were reinforced especially through the organizational independence of the three stock companies and the Ministry. Moreover, a new boundary was introduced between a supervisory ministerial department and the newly established regulatory agency.

2. By affecting their boundaries, the reform process changed the selection criteria of relevant sub-systems. The complete separation of supervisory and economic functions allows the newly established stock corporations to concentrate on their economic performance and relieves them from having to concern themselves with issues such as regional minimum supply of infrastructure. Likewise, the supervisory sub-systems are relieved from paying attention to the economic well-being of companies and the details concerning the supply of services. They may concentrate their activities on regulation. Hence, postal reform fostered specializa- 
tion of the sub-systems involved on more clearly distinct selection criteria. Everything else being equal, we may expect better performance of the corporations in the market because they operate exclusively according to their economic rationale, and we may also expect regulation to be better because it is limited to supervisory functions complementary to economic decision-making. If the separation of the two regulatory sub-systems - a ministerial department and the regulatory agency - makes sense, it will contribute to enhancing regulatory performance. This issue deserves closer inspection in the next section.

3. Postal reform modified the mechanisms by which the operation of the autonomous sub-systems involved is integrated into a meaningful whole. Originally, sub-systems of the postal authority as a whole were integrated by hierarchical order and a common interest into the stability of the system. For example, the Ministry could order the telecommunications branch to invest in East Germany even if this were not within its own economic rationale, or to cross-subsidize traditional postal services. This integration mechanism had de-autonomizing or de-differentiating effects because it did not respect the operational autonomy of the respective sub-systems. After postal reform, the integration of complementary functions no longer relies on these mechanisms. Some of the new integration mechanisms are quite obvious. For example, the relationship of the privatized companies to each other and their competitors is now governed by market principles. Likewise, companies will, in their own economic interest, pay attention, although not necessarily always adhere, to regulatory decisions. Other mechanisms are less obvious: How are the activities of the two autonomous regulatory bodies (i.e., the Ministry and the agency) integrated? And how do the activities of the economic actors affect the regulatory activities? These issues will be inspected more closely below.

\section{Separation of the functions of rule-making and rule-application}

\section{Division of labor between regulatory agents}

German telecommunications regulation is characterized by a systematic separation between the legislative functions performed by parliament and the Ministry, on the one hand, and the application function assigned to the agency, on the other. The legislative function deals with enacting legally binding and general rules designed to last for a comparatively long period of time (although they may be amended at any time, if deemed appropriate) and are 
applicable to several, possibly many, cases. Parliament as well as, within its delegated competence, the Ministry enjoy a considerable margin of discrete choice based on their political (parliamentary) accountability. However, their activity is limited to providing a set of generally applicable and legally binding rules as detailed as may be deemed appropriate.

The German telecommunications statute (Telekommunikationsgesetz) adopted by the two chambers of parliament provides a rather detailed legal framework, especially for three areas of expected market failure (Geppert et al. 1998). First, in order to create competition in an originally monopolized market, competitors and providers of particular services (e.g., operators and re-sellers) enjoy a right of access to the Telekom network at reasonable and controlled prices. In order to protect small competitors, the former monopoly supplier is prohibited from subsidizing highly competitive sectors with revenues from still non-competitive sectors. Second, the statute provides for countrywide minimum services at a comparatively high standard and at reasonable prices (so-called 'universal service'). If Telekom no longer provides this service, tenders will be invited and the costs split between suppliers of a reference region according to their market shares. Third, the statue addresses issues of technical and organizational standardization (e.g., distribution and compatibility of telephone numbers) as well as questions of the distribution of tight resources (e.g., frequencies for mobile phoning).

Parliament and the Ministry perform the legislative function together. In the German system, detailed and technically complicated legislation like this is in practice largely prepared and drafted by the responsible ministry. Subsequently, the statute is widely discussed in parliament and reflects the opinion of a wide majority of parliamentarians. This functional division of labour is typical for parliamentary systems in which the head of government is elected by a parliamentary majority and ministers are immediately accountable to this majority. In fact, the legislature not only entrusted preparatory work to the Ministry. The statute also empowers it to enact secondary legislation. So far, six ordinances have been created dealing with, inter alia, pricing policies, the rights of customers and access to networks (Geppert et al. 1998).

In contrast to the legislative function, the Regulatory Agency on Telecommunication and Post performs an executive function. According to its statute, it specializes in case-by-case decision-making in all three areas of regulated market failure: regulation of competition, technical and organizational coordination, and assurance of minimum services. It distributes phone numbers and auctions mobile phone licenses (UMTS). To support it in its regulatory task, the agency enjoys far-reaching rights of investigation, search and seizure, as well as sanctioning powers (Gramlich 1997: 636-637). However, its organizational core is made up of its five decision chambers, which operate in 
a formalized and court-like procedure that is public and based on oral deliberation.

Through its decisions, the agency reacts swiftly to conflicts in the market that had not been envisaged by the legislature. It may start investigation on its own, for example, if it becomes aware of illegal activity among market participants. Moreover, prices charged by Telekom have to be approved ex ante. In recent years, the agency has repeatedly refused to approve excessively low prices in highly competitive sectors (Handelsblatt, 17 March 1999), or extraordinarily high prices in still monopolized areas (press releases of 20 January 1999 and 8 February 1999, available online at: www.regtp.de). The decisionmaking mechanism may also be triggered by an interested supplier unable to settle a conflict with a competitor. In this way, the agency has decided several important cases that heavily influence the market for telecommunication services. It held, for example, that telephone numbers may be transferred without costs from Telekom to other suppliers (press release of 7 April 1998) and obliged Telekom to issue bills containing the charges of competitors from 'callby-call' phoning (press release of 21 February 2000).

While the agency has not been granted any explicit margin of discrete choice in these areas, its decisions gain relevance because the general (i.e., not case-specific) rules of the statute and accompanying ordinances are inevitably incomplete (Williamson 1987: 23) and require interpretation. In setting precedents and deciding cases, it also creates law, but it does so on the basis of the general rules enacted elsewhere. For example, the statute provides that Telekom prices for connecting networks must be based on the "efficient provision of services' principle so that the company may only demand that part of its actual costs that an efficient company would have had to charge. But what do the costs of the efficient provision of services include? While Deutsche Telekom had demanded that its 'neutral costs' (including investments in East Germany and pensions of its former civil servants) be reimbursed, costs were originally fixed at the arithmetic mean between the average of ten comparable countries and the three cheapest countries (Geppert et al. 1998: 308-318). Neither the reference countries, nor the procedure, nor even the structure of the tariff system were provided for in law.

Generally, parliament and the Ministry could have fulfilled all necessary regulatory functions on their own. It is the establishment of an additional subsystem specialized in case-by-case decisions that deprives the Ministry of a sub-set of regulatory decision-making. As a consequence, it specializes in auxiliary legislative functions. Hence, the regulatory system is characterized by the fact that neither of the two sub-systems involved is in control of all competencies needed for successful regulation. 
An explanation for the separation of rule-making and rule-application

Is the established division of labour between making the law and applying it reasonable? It will be no surprise that parliament delegates case-by-case decision-making to an administrative body because it could hardly fulfil this function properly (Strøm 2000). However, it could have delegated it to the Ministry, as it did before 1998. The Ministry had sufficient technical expertise, and could easily develop the necessary economic expertise, to regulate the market. The agency is hardly more competent than the Ministry would have been (in fact, its staff largely comes from the old Ministry). Hence, the puzzle is not why there was delegation, but why decision-making power was delegated to a comparatively independent agency operating largely apart from ministerial intervention.

In order to investigate the systematic implications, the advantages and disadvantages of the establishment of a largely independent regulatory agency within a democratic system, the following hypothetical question must be answered: Under what conditions will it be reasonable for a parliamentary majority to refrain from adopting implementing decisions under its own close control and assign this task to an independent agency? Generally, rational actors will only delegate in this way if they anticipate that their intervention in subsequent decision-making might counteract their own interests. This will not be the case for actors who are aware of their interests, have a consistent order of preferences and behave accordingly. However, in some situations, actors may have long-term interests that contradict their short-term (i.e., situation-specific) preferences so that their order of preferences is inconsistent (Keech 1995: 38-40). Consider a political actor (say, state or government) faced with a case of hostage-taking. It will be in its long-term interest to develop a reputation of generally not negotiating with hostage-takers in order to reduce the incentive for future crimes. Nevertheless, there may be good reasons in the specific situation to save the lives of hostages (say, a group of children) by negotiation, even though the negative long-term implications are well-known. The state or government determines its long-term interests at point $t_{1}$, but - for whatever reason - ignores them in a given situation at $t_{1}$ and will regret its decision later at point $t_{2}$ (Elster 1979:67-68). In light of its inconsistent order of preferences, it may pursue its short-term preferences only at the expense of its long-term interests - and vice versa. It finds itself in a dilemma somewhat like the Prisoners' Dilemma, played against 'nature', or better: against itself.

The problem of the inconsistency of preferences over time is relevant for the regulation of telecommunication markets. Generally, the problem is 
well-known in democracies. Policies with a positive effect for public welfare may be difficult to implement because elected politicians have an incentive to calculate in terms of election periods - with a comparatively short time horizon (Shepsle 1991: 250-252) - because they may increase their prospects of re-election by 'election gifts', or because the public discounts future gains of painful reforms in light of their immediate costs. The problem occurs more specifically in the long-term regulation of telecommunication markets. On the one hand, support of postal reforms in Germany by a broad majority of the members of both chambers of parliament indicates a general interest in transforming the originally state-controlled telecommunications sector into a competitive market, if only to attract private investors in an area characterized by huge sunk costs of investment (Majone 1999: 5-6). On the other hand, the stream of regulatory decisions to be made over time has major implications for the competitive advantage of particular suppliers; it determines the speed and scope of structural transformation of Deutsche Telekom from an originally state-run authority into a competitive company; it influences the market value of Telekom, which is still to a significant degree state-owned; and it affects matters of regional interests (e.g., employment and supply with telecommunication services). Whereas all these issues are important and politically relevant, their intervention into day-to-day decision-making would inevitably jeopardize the long-term goal of establishing and maintaining a competitive telecommunications market and attracting new investors. Were politically accountable actors responsible for adopting these decisions and legitimating them vis-à-vis their voters, they would inevitably find themselves in the dilemma of inconsistent preferences (Pollack 2002: 208).

The dilemma of inconsistent preferences will diminish over time if the time horizon of the decision-making system is systematically enlarged by appropriate institutional arrangements. Some 'credible commitment' (Shepsle 1991) beyond the mere determination of political representatives is needed to take long-term interests into account (Elster 1979: 42). To resist the temptation of the concrete situation, actors must sacrifice their margin of choice in the concrete situation (Elster 1979: 38, 2000: 65-77) and bind themselves to a suitable 'mast' like Ulysses did when faced with the Sirens. The 'mast' available in modern society is an appropriate institutional restraint. A parliamentary majority and a government delegating implementing decisions to an actor that is unsusceptible to the temptations of specific situations will credibly bind themselves. They seek to avoid exposing themselves to the specific decision situation (Cukierman 1994). The almost complete independence of the German regulatory agency and of other agencies regulating public utilities (Thatcher 1998) provides the institutional prerequisite for this separation (Keech 1995: 154; Majone 1999: 4-6). 
Delegation of implementing decisions to an independent agency leads to the differentiation of two functions that are indispensable for successful regulation. The general (i.e., long-term) interests of society in the sector are determined by a parliamentary majority. In contrast, the application of the general rules to numerous specific situations is performed in a way that excludes, as far as possible, situation-specific and opportunistic considerations by a sufficiently strict separation of decision-making from the grip of the ruling parliamentary majority. Hence, depending on their time horizon, regulatory decisions are adopted by different actors according to different selection criteria.

To conclude, the distinction between long-term interests and situationspecific (opportunistic) preferences explains the independence of regulatory agencies. Legitimate decisions about long-term interests pose other difficulties than the case-by-case application of these decisions to particular situations. Accordingly, the two tasks require different institutional arrangements and are best performed separately from each other. While regulatory decisionmaking may appear to be concentrated on the established agency, legislation is in fact equally important for successful regulation.

\section{Consequences of the institutionalized division of regulatory functions}

\section{Discursive rule-making}

Effects of the separation of functions on the rule-making process will have to be assessed against the null hypothesis that a majority-supported legislature and a fully controlled ministry both prepare and adopt general rules and apply these rules to cases or adopt implementing decisions. However detailed legislative provisions are, they will always be incomplete (Williamson 1987) and will not cover all possible decision situations. This is not a serious problem for a majority that controls implementation because general rules are permanently interpreted and - implicitly - modified according to its own will. Decision-making conditions will change profoundly if the majority loses immediate control over implementation decisions.

If politically legitimated action is limited to the adoption of general rules, it will be more difficult to accommodate parochial interests. The making of general rules that apply to an unknown number of future cases renders it difficult to pursue parochial interests (Brennan \& Buchanan 1985: 28-31). Frequently, rule-making will take place before relevant political actors become aware of their situation-specific (e.g., regional or interest group-related) particular preferences. Actors must decide about general rules without being 
aware of their exact parochial interests, especially if the rules are expected to be valid for a longer period of time and the rate of change in the regulated sector is high. Hence, political actors making general rules tend to operate under a Rawlsian 'veil of ignorance' (Rawls 1971). Even if political actors fully anticipate specific decision situations and their preferences in these situations, they will be forced to identify an aggregate overall interest. A region like Bavaria with high-technology locations and remote border areas can no longer separately pursue its interests in a liberalized market and in the provision of high-standard minimum infrastructure and in the fate of Telekom as a major regional employer. It is now forced to develop a consistent overall preference that will almost automatically balance extreme positions.

If their strategies are ill-determined, even rational utility maximizers will be inclined to search for rules promising outcomes that are generally acceptable. Actors that are not aware of their parochial interests cannot pursue them by classical bargaining (Elster 1989). They are faced with the common problem of identifying rules that ensure acceptable implementation decisions independently of their (yet unknown) situation-specific preferences (Tsebelis 1990: 115-118). This task will be facilitated by discursive interaction based on the exchange of reasonable arguments (Vanberg \& Buchanan 1989; Elster 1998). Political negotiations about sufficiently general rules tend thus to approach a Habermasian discourse (Habermas 1992) in which reasons rather than power and sanctions dominate interaction and influence collective decisions (Gehring 2003).

The separation of regulatory functions provides incentives for rational utility maximizers to change to discursive interaction and facilitates a process of rule-making that does not, in the first place, rely on the balancing of clearcut preferences. Parochial interests, whether well-founded or not, will hardly be completely absent in practice, and political actors may be inclined to bargain even if they are quite unaware of their 'real' future preferences. The argument here is that functional differentiation helps mobilize an additional mechanism to increase regulatory performance based on the common search for acceptable solutions independent of power and interests.

\section{Discursive decision-making also at the application level?}

Decisions at the rule-application level raise the problem of accountability beyond close control. Effective delegation of decision-making power always implies a thread of abuse. It raises the question of how to provide appropriate incentives to the agency in order to prevent abuse (Kiewiet \& McCubbins 1991; Moe 1990). If the institutionalized separation of regulatory functions is a response to the problem of inconsistent preferences, it must be ensured that 
the agency operates according to the long-term interests of the legislature. However, close oversight by the legislature would almost automatically jeopardize its intention of binding itself to its long-term interests and of avoiding interfering in situation-specific decision-making. While 'agency-shirking' is not a negligible problem, the agency requires a high degree of autonomy to discharge its functions properly (Majone 2001). Hence, suitable incentives must be sought elsewhere. They will immediately depend on the precise institutional arrangements as well as the underlying conditions of regulation.

Formally, the German regulatory agency is merely semi-independent at best. The Ministry may not decide cases in the place of the agency, and it may not change agency decisions after the fact (Geppert at al. 1998: 534). However, it is empowered to issue 'general' (i.e., not case-specific) directives that are published in the Federal Gazette (Bundesanzeiger) and attract considerable public attention. It also appoints the head of the agency as well as the members of the decision chambers, and may replace them at any time. These arrangement are largely a consequence of the peculiarities of German constitutional law (Döhler 2002: 104-105). They are intended to establish at least the fiction (Gramlich 1998: 464) of some remote ministerial responsibility.

Despite formal ministerial powers, the regulatory agency poses problems of legitimacy and control typical for independent agencies. While the occasional use of remaining oversight powers cannot be excluded, their employment in response to undesired decisions would cause comparatively high political costs because of their visibility (Majone 1999: 15). Moreover, the established institutional arrangement would necessarily be undermined. Therefore, ministerial powers do not provide a useful mechanism for overseeing 'normal' day-to-day decision-making of the agency, nor can they legitimize these decisions. They constitute at best an emergency break, usable only in extreme situations. It is worth noting that the regulatory agency enjoys a degree of formal independence beyond that of the Federal Cartel Office (Bundeskartellamt), which developed an international reputation for independent decision-making (Baake \& Perschau 1996).

Even under the assumption of a complete de facto separation of the functions of rule-making and rule-application, independence is not necessarily an indicator of arbitrariness in decision-making and an absence of control and legitimacy. Not even a fully 'independent' agency is independent from parliament enacting relevant statutes, or from the judiciary appraising its decisions (Shapiro 1997:278). Two interconnected social mechanisms may be identified that provide appropriate incentives even to independent agencies. One supervisory mechanism operates by legislative activity. At first glance, it may seem that legislature and ministry are out of the game once they have established the system. However, the legislature exerts continuously significant influence 
on day-to-day decision-making by providing substantial and procedural rules before a particular application decision is adopted (Huber et al. 2001; Bawn 1997; Epstein \& O'Halloran 1994). It is potentially the most definitive set of instructions that can be given to an agency with respect to the actions it must take during policy implementation. In the case of the German agency, these instructions include numerous substantive and procedural rules guiding the operation of the supervisory apparatus.

In order to fulfil its programming function, legislation must really reflect the long-term interests of the principal and may have to be adapted to new circumstances. Application decisions can hardly be more reasonable than the rules that are applied. Outdated legal instructions that no longer reflect the long-term interests of the legislature, as well as ill-designed rules that create difficulties at the implementation level, will not provide the appropriate incentives. Successful integration of the rule-making and rule-application functions is part of the job of the legislature when providing general rules that allow reasonable application decisions. Accordingly, it is among parliamentary and ministerial functions to observe the operation of the regulatory system carefully - either systematically in the form of police patrols or more incidentally by becoming sensitive to conflicts and 'fire alarm' signals (McCubbins \& Schwartz 1987). If necessary, statutes must be revised in order to reprogramme secondary decision-making by the agency and relevant courts. In a functionally divided regulatory system, the appropriate legislative and ministerial response to conflicts is the making of new general rules, not intervention into case-by case decision-making.

A second mechanism is based on the supervisory function of courts (Shapiro 1988). Courts are specialized in appraising concrete action in the light of general rules. Because of their specific mode of operation and their own independence, they are also largely precluded from judging on the basis of situation-specific preferences and, implicitly, programmed to implement the legislature's long-term interests as reflected in the law. If an agency enjoys almost no explicit margin of discrete choice, as is the case for the German regulatory agency, a court will also examine whether the decision constitutes a reasonable interpretation and application of relevant general provisions. It will inquire into how the agency reached its decision. Accordingly, the agency may expect to be asked to provide reasons for the appropriateness of its decision in light of possible alternatives.

Anticipation of subsequent court appraisal provides a strong incentive for the agency to reach decisions that could have been reached in a discourse characterized by the absence of power and parochial interests. Habermas (1992: 138, my translation) argues that 'norms of behaviour that are valid are precisely those which could be agreed upon by all those possibly affected, if 
they were participants in rational discourses'. In light of the possibility of court appraisal, an agency will strive for decisions that are supported by convincing reasons and therefore increase the probability of approval by responsible courts, rather than pursue arbitrary goals. The 'giving-reasons requirement' (Shapiro 1992) creates, in turn, an interest on the part of the agency in becoming aware as early as possible of alternatives, and the opinions of relevant actors and accompanying reasons. The agency will, in its own interest, organize hearings and consultations with these private parties and sincerely take the information thus gathered into account when deciding a pending conflict (Thatcher 1998: 131). Moreover, reasonable arguments must be processed in ways that ensure convincing results. Accordingly, an agency will be interested in engaging in a discursive appraisal of arguments on the proper application of mandatory rules to a particular decision situation. This does not require consensus among all interested parties. The agency will merely create a triadic interaction situation typical of courts in which the adversarial parties produce arguments that are subsequently appraised and weighed against each other by a third party.

A prerequisite for the proper operation of this method of making an agency accountable to the public is that court supervision is really anticipated. There must be a certain minimum probability that proceedings are in fact instigated. The mechanism will operate particularly well if many actors whose interests are possibly affected have legal standing. In some cases, this condition is hardly fulfilled. For example, it is virtually impossible to instigate court proceedings against decisions of independent central banks. In contrast, decisions of the regulatory agency immediately affect particular third parties (usually firms) that have legal standing. Its decisions may always be, and frequently are, subject to court decision-making (Müller 2001: 59-60).

Integration of the rule-making and the rule-application functions is not only ensured from 'above' (i.e., by the principal), but also from 'below'. In Principal-Agent language, one might say that the legislature not only delegates decision-making but also oversight functions (Kiewiet \& McCubbins 1991: 33-34). In the first place, oversight is delegated to existing courts that become an additional sub-system in the chain of regulatory decision-making specialized to the appraisal of regulatory decisions in light of valid rules. In the second place, it is delegated to numerous self-interested sub-state and non-state actors (here predominantly the competitors in the telecommunication market) that trigger the decision-making process. In this institutional arrangement, high-quality regulatory decisions are the result of interaction between three types of sub-system, all of which enjoy considerable autonomy and none of which must be assumed to voluntarily adopt the perspective of the legislature. 
To conclude, the institutionalized separation of regulatory functions facilitates discursive decision-making at the agency level, too. The appropriate separation of regulatory functions generates an agency interest in producing reasonable decisions. Ideally, its discrete choice will be limited to the selection of one out of a number of equally reasonable options, if there are any alternatives. In practice, supervision will never be complete and distortions will occur. Therefore, it is merely claimed that the separation of functions supports deliberative decision-making and promises more reasonable decisions than reliance on the power of majorities or bargaining processes.

\section{Conclusion}

In contrast to the dominant Principal-Agent approach, the approach developed in this article is designed to address both independence and oversight. Establishing an independent agency automatically separates regulatory functions and limits the activities of a legislature, or those of a closely controlled ministry, to some of the functions originally performed. In this type of institutionalized division of labour, complementary functions are fulfilled by specialized sub-systems operating according to their own rules. Tight oversight of its activities by a principal would partially or entirely deprive an agency of the autonomy required to perform its functions and undermine the regulatory system. Yet, independence from parliamentary or ministerial intervention and operational autonomy of an agency does not necessarily mean high degrees of freedom and an almost unlimited ability to adopt arbitrary decisions.

The German system for the regulation of the telecommunications market exemplifies the relevance of functional differentiation. While telecommunications services in Germany were originally supplied by an encompassing postal authority, the system is today characterized by interaction of a number of autonomous units, each of which operates according to its own rationale. Postal reforms not only separated the economic rationale of stock corporations from the political rationale of state supervision, they also separated the making of general rules, retained by the legislature and a ministry, from the application of these rules through case-by-case decision-making, assigned to a comparatively independent regulatory agency. This separation of regulatory functions is explained by the probable inconsistency of long-term interests and short-term preferences. Apparently, the German legislature desired to bind itself by an appropriate institutional arrangement.

On closer inspection, however, establishing an independent agency not only constituted an appropriate institutional response to the problem of inconsistent preferences, it also promised to facilitate discursive (deliberative) inter- 
action over power-based decision-making at both the legislative and the agency levels. Decisions at the former level tend to be taken under a Rawlsian 'veil of ignorance' that forces even rational utility maximizers to deliberate rather than bargain because actors decide exclusively about general rules applicable to an unknown number of future cases. Decisions at the latter level are influenced by the fact that the agency, while not enjoying any explicit margin of discrete choice, generates an interest in producing reasonable decisions because it must anticipate their subsequent appraisal by the judiciary. The appropriate separation of the two functions of rule-making and rule-application triggers a social mechanism that will, ideally, bring about Habermasian communicative action even in a setting characterized by vested interests.

These benign consequences of the institutionalized separation of functions are not unique to the regulation of telecommunications in Germany. They may be far more widespread than assumed from a traditional Principal-Agent perspective. The general causal mechanism may be expected to operate if the following three conditions are fulfilled. First, functions must be effectively separated. What matters is actual rather than formal autonomy. This condition will not only be fulfilled by formally independent agencies like those regulating public utilities in an increasing number of states, but it may also be fulfilled by large parts of non-ministerial public administrations in European countries that traditionally enjoy a high degree of autonomy. Second, discursive interaction at the political (rule-making) level will depend on the inability of actors to identify and pursue their case-specific interests. Whether this is the case will depend not least on the subject matter to be regulated. This condition will not be fulfilled if a majority outvotes a minority on substance. Third, decisions adopted at the lower (application) level will have to be made in light of meaningful legislative instructions of a more general type. Functions do not necessary have to be divided exactly between rule-making and rule-application. Some agencies have the power to make rules. What matters is that decision-makers can be, and effectively are, made accountable for their decisions.

\section{References}

Baake, P. \& Perschau. O. (1996). The law and policy of competition in Germany. In G. Majone (ed.), Regulating Europe. London: Routledge, pp. 131-156.

Bawn, K. (1997). Choosing strategies to control the bureaucracy: Statutory constraints. oversight and the committee system. Journal of Law, Economics and Organization 13: 101-126.

Benz, A. (1997). Privatisierung und Regulierung im Post- und Fernmeldewesen. In K. König \& A. Benz (eds.), Privatisierung und staatliche Regulierung. Bahn, Post und Telekommunikation, Rundfunk. Baden-Baden: Nomos Verlagsgesellschaft, pp. 262-346. 
Berger, H. (1993). Zwischen Postreform I und Postreform II. Zeitschrift für öffentliche und gemeinwirtschaftliche Unternehmen 16: 80-95.

Brennan, G. \& Buchanan, J. (1985). The reason of rules: Constitutional political economy. Cambridge: Cambridge University Press.

Coleman, J.S. (1990). Foundations of social theory. Cambridge, MA: Belnkamp.

Cukierman, A. (1994). Commitment through delegation: Political influence and central bank independence. In J. Onno de Beauford Wijnholds, S.C.W. Eijffinger \& L.H. Hoogduin (eds.), A framework for monetary stability. Dordrecht: Kluwer, pp. 55-74.

Döhler, M. (2002). Institutional choice and bureaucratic autonomy in Germany. West European Politics 25(1): 101-124.

Egan, M. (1998). Regulatory strategies, delegation and European market integration. Journal of European Public Policy 5(3): 485-506.

Elster, J. (1979). Ulysses and the Sirens: Studies in rationality and irrationality. Cambridge: Cambridge University Press.

Elster, J. (1989). The cement of society: $A$ study of social order. Cambridge: Cambridge University Press.

Elster, J. (ed.) (1998). Deliberative democracy. Cambridge: Cambridge University Press.

Elster, J. (2000). Ulysses unbound: Studies in rationality, precommitment and constraints. Cambridge: Cambridge University Press.

Epstein, D. \& O'Halloran, S. (1994). Administrative procedures, information and agency discretion. American Journal of Political Science 38: 697-722.

Epstein, D. \& O'Halloran, S. (1999). Delegating powers: A transaction cost politics approach to policy making under separate powers. Cambridge: Cambridge University Press.

Gehring. T. (2003). Communicative rationality in European governance? Interests and communicative action in functionally differentiated single market regulation. In E.O. Eriksen, C. Joerges \& J. Neyer (eds), European governance, deliberation and the quest for democratisation. Oslo: Arena Report No. 02/2003, pp. 57-140.

Geppert, M., Ruhle, E.-O. \& Schuster, F. (1998). Handbuch Recht und Praxis der Telekommunikation. Baden-Baden: Nomos Verlagsgesellschaft.

Gramlich. L. (1997). Entwicklungen der staatlichen Wirtschaftsaufsicht: Das Telekommunikationsrecht als Modell? Verwaltungsarchiv 88: 598-644.

Gramlich, L. (1998). Ohne Regulierung kein Wettbewerb. Zum Start der Regulierungsbehörde für Post und Telekommunikation. Computer und Recht 14: 463-472.

Habermas, J. (1992). Faktizität und Geltung. Beiträge zur Diskurstheorie des Rechts und des demokratischen Rechtsstaates. Frankfurt-am-Main: Suhrkamp.

Hancher. L. \& Moran, M. (1989). Organizing regulatory space. In L. Hancher \& M. Moran (eds), Capitalism, culture and economic regulation. Oxford: Clarendon Press, 271-299.

Hopenhayn, H. \& Lohmann, S. (1996). Fire-alarm signals and the political oversight of regulatory agencies. Journal of Law, Economics and Organization 12(1): 196-213.

Huher, J.D. (2000). Delegation to civil servants in parliamentary democracies. European Journal of Political Research 37(3): 397-413.

Huber. J.D., Shipan, C.R. \& Pfuhler, M. (2001). Legislatures and statutory control of bureaucracy. American Journal of Political Science 45(2): 330-345.

Humphreys, P. (1992). The politics of regulatory reform in German telecommunications. In K. Dyson (ed.), The politics of German regulation. Aldershot: Dartmouth, pp. 105-135.

Keech, W.R. (1995). Economic policy: The costs of democracy. Cambridge: Cambridge University Press. 
Kiewiet, R. \& McCubbins, M.D. (1991). The logic of delegation: Congressional parties and the appropriations process. Chicago, IL: University of Chicago Press.

Luhmann, N. (1984). Soziale Systeme. Grundriß einer allgemeinen Theorie. Frankfurtam-Main: Suhrkamp (2nd edn., 1988).

Luhmann, N. (2000). Organisation und Entscheidung. Opladen: Westdeutscher Verlag.

Majone, G. (ed.) (1996). Regulating Europe. London: Routledge.

Majone, G. (1999). The regulatory state and its legitimacy problems. West European Politics 22(1): 1-24.

Majone, G. (2001). Nonmajoritarian institutions and the limits of democratic governance: A political transaction-cost approach. Journal of Institutional and Theoretical Politics 157: 57-78,

Mayntz, R. (1988). Funktionale Teilsysteme in der Theorie sozialer Differenzierung. In R. Mayntz et al., Differenzierung und Verselbständigung. Zur Entwicklung gesellschaftlicher Teilsysteme. Frankfurt-am-Main: Campus Verlag, pp. 11-44.

McCubbins, M.D. \& Schwartz, T. (1987). Congressional oversight overlooked: Police patrols versus fire alarms. American Journal of Political Science 28(1): 165-179.

McCubbins, M.D., Noll, R.G. \& Weingast, B.R. (1987). Administrative procedures as instruments of political control. Journal of Law, Economics and Organization 3(2): 243 277.

Moe, T.M. (1990). The politics of structural choice: Toward a theory of public bureaucracy. In O.E. Williamson (ed.), Organization theory: From Chester Barnard to the present and beyond. New York: Oxford University Press, pp. 116-153.

Müller, M.M. (2001). Restructuring the new regulatory state in Germany: Telecommunications, broadcasting and banking. German Politics 10(3): 37-64.

Münch, R. (1994). Sociological theory, Volume III: Developments since the 1960s. Chicago, IL: Nelson-Hall.

Niskanen, W.A. (1971). Bureaucracy and representative government. Chicago, IL: Aldine.

Pollack, M. (2002). Learning from the Americanists (again): Theory and method in the study of delegation. West European Politics 25(1): 200-219.

Rawls, J. (1971). A theory of justice. Cambridge, MA: Harvard University Press.

Riehmer, K.W. (1995). Organisation und Regulierung der Telekommunikation in Deutschland. In E.-J. Mestmäcker (ed.), Kommunikation ohne Monopole II. Ein Symposium über Ordnungsprinzipien im Wirtschaftsrecht der Telekommunikation und der elektronischen Medien. Baden-Baden: Nomos, pp. 369-395.

Schmidt, S. (1996). Privatizing the federal postal and telecommunications services. In A. Benz \& K.H. Goetz (eds.), A new German public sector? Reform, adaptation and stability. Aldershot: Dartmouth, pp. 45-70.

Schmidt, S.K. (1998). Commission activism: Subsuming telecommunications and electricity under European competition law. Journal of European Public Policy 5(1): 169-184.

Shapiro, M. (1988). Who guards the guardians? Judicial control of administration. Athens, GA: University of Georgia Press.

Shapiro, M. (1992). The giving-reasons requirement. University of Chicago Legal Forum: $180-220$.

Shapiro, M. (1997). The problem of independent agencies in the United States and the European Union. Journal of European Public Policy 4: 277-291.

Shepsle, K.A. (1991). Discretion, institutions and the problem of government commitment. In P. Bourdieu \& J.S. Coleman (eds.), Social theory for a changing society. Boulder, CO: Westview Press, pp. 245-263. 
Shepsle, K.A. (1992). Bureaucratic drift, coalitional drift and time-consistency: A comment on Macey. Journal of Law, Economics and Organization 8(1): 111-118.

Steinmetz, H. (1956). Die staats- und verfassungsrechtliche Stellung der deutschen Bundespost. Jahrbuch des Postwesens 6(1955/1956): 18-54.

Stone Sweet, A. (2002). Constitutional courts in parliamentary democracy. West European Politics 25(1): 77-100.

Strøm, K. (2000). Delegation and accountability in parliamentary democracies. European Journal of Political Research 37(3): 261-289.

Thatcher, M. (1998). Institutions, regulation and change: New regulatory agencies in British privatized utilities. West European Politics 21(1): 120-147.

Thatcher, M. \& Stone Sweet, A. (2002). Theory and practice of delegation to nonmajoritarian institutions. West European Politics 25(1): 1-22.

Tsebelis, G. (1990). Nested games: Rational choice in comparative politics. Berkeley, CA: University of California Press.

Vanberg, V. \& Buchanan, J.M. (1989). Interests and theories in constitutional choice. Journal of Theoretical Politics 1(1): 49-62.

Werle, R. (1990). Telekommunikationspolitik in der Bundesrepublik. Expansion, Differenzierung, Transformation. Frankfurt-am-Main: Campus.

Williamson, O.E. (1987). The economic institutions of capitalism. New York: Free Press.

Address for correspondence: Thomas Gehring, University of Bamberg, Faculty of Social and Economic Sciences, Feldkirchenstrasse 21, D-96045 Bamberg, Germany

Tel.: +49 951863 2720; Fax: ++49 951863 1200; E-mail: Thomas.Gehring@sowi.unibamberg.de 